\title{
Lessons from Confucius Ideas: Chinese Universities' African Students Reflections
}

\author{
Samson Chaima Robin Kajawo \\ International Center for Teacher Education, East China Normal University, Shanghai, China \\ Email: samsonkajawo@gmail.com
}

How to cite this paper: Kajawo, S.C.R. (2019) Lessons from Confucius Ideas: Chinese Universities' African Students Reflections. Open Access Library Journal, 6: e5693. https://doi.org/10.4236/oalib.1105693

Received: August 9, 2019

Accepted: August 26, 2019

Published: August 29, 2019

Copyright (C) 2019 by author(s) and Open Access Library Inc.

This work is licensed under the Creative Commons Attribution International License (CC BY 4.0).

http://creativecommons.org/licenses/by/4.0/ (c) (i) Open Access

\begin{abstract}
In most normal universities in China, Confucian lessons are included in the international students study programs. This is because Confucianism is the most prevalent deep rooted historical philosophy in China. It is based on the teachings of Confucius (551 - 479 B.C.), a virtuous man who never wanted to be associated with insincerity, immorality and corruption. Though he failed to implement his ideas when he was alive, he lived forever and became "a king without a crown" when his principles were accepted and implemented by Chinese authorities many hundred years later, which has partly contributed to the current socio-economic landscape of China. In contrast, Africa continues to face a lot of challenges chiefly caused by moral degradation and poverty. Do Confucian lessons have an impact on the African students who study them? This paper qualitatively analyzed the views of ten former African students in China regarding Confucius and his philosophies and their reflections on how Africans can benefit from the ideas and philosophies of this Great Sage. The key finding was that the majority of respondents acknowledged that they indeed took home a lot of lessons from their studies regarding Confucius and his philosophies. It was also noted that Confucius studies made the majority of these foreign students to understand the values of selflessness and virtuous life in leadership as well as the importance of expanding access of education for the benefit of all people. Africa can surely develop if leaders tap lessons from these kinds of philosophies.
\end{abstract}

\section{Subject Areas}

Education, History, Linguistics, Philosophy

\section{Keywords}

Confucius, African Challenges, Chinese Philosophy, Confucianism, African Culture 


\section{Introduction}

Each country on earth has its own history. This history could include its great leaders, culture and unique philosophies of life. Unfortunately, in most countries, those rich values of the nations have been forgotten in the passing of time due to the forces of modernization and westernization which have eroded the true value of living as inscribed by their forefathers [1] [2] [3]. But this is not the case with China. Chinese people have a very long history of their ancestors, culture and national ideological systems. It is amazing how this rich deep rooted cultural and historical heritage has been preserved to have a very strong effect on the lives of the people of this great nation up to now. From my teen days, I had learned a lot about China. I first learned about Chinese traditions through watching Kungfu movies that depicted life at Shaolin temples and Buddhist practices and beliefs. Growing up, I read books about China that talked about its culture and traditions. I got a job that got me posted, at one time, to a station in Blantyre, Malawi. Nearer to my workplace was the Amitofo Centre, a Chinese cultural and orphan care centre which had a Buddhist Temple inside the campus, where I was privileged to attend to various Chinese and other specific Buddhist traditional events. All these encounters formed a perception in me that Buddhism was the most popular religion in China. But the moment I stepped my foot in the land of the People's Republic of China, I immediately noticed that the Chinese culture was very rich. It is molded by three philosophical traditions, Confucianism, Taoism, and Buddhism.

My trip to Shandong province in the City of Qufu, Confucius' birthplace later opened my eyes further to the world of Chinese culture and customs. These are the international historical sites where millions of people come each year to see and pay tribute to the Great Man at His temple, grave and family home, and also at the Apricot Pavilion where Confucius taught his students. Some burn incense and bow before the central statue of Confucius. Being there in fresh, I was very happy and excited. We took pictures while listening to the soft speaking tour-guide. Our visit to Confucius and Mencius memorial sites was undeniably a memorable one. It made me understand why UNESCO made this place one of the World Heritage Sites.

In our studies, we later learned that to the Chinese, Confucianism is not a religion. It is a system of thought based on the teachings of Confucius, who lived from 551 to 479 B.C. [4]. In Chinese language, this Great Man's name was 孔夫 子 (Kŏng Fūž̀) or "Kong Fuzi", or "Master Kung" [5]. Confucius was born in 551 B.C. in a small city called Lu during the period in which the Zhou dynasty was in decline [1]. Little is reliably known about Confucius' childhood, though Confucius himself remarked: "I was of lowly status when I was young. That is why I am skilled in many things" [6]. It is also recorded that from his earliest years, Confucius had a passion for study. Like other students of the time, he learned from books made of strips of bamboo bound by cords [7].

It is recorded that Confucius held various government positions in the state of 
$\mathrm{Lu}$ [8]. However, he lateron decided to resign from his post in protest of the immoral conduct of the Lu ruler in 497 B.C. This made him leave his native state of $\mathrm{Lu}$, hoping to find a ruler more receptive to his ideas about good governance. Unfortunately, Confucius did not have any luck since no ruler was accommodative to his leadership ideas; hence he was forced to settle for a life of teaching till his death in 479 B.C. [1].

The last days of Confucius' life were full of regrets, bitterness, and despair since he thought he had failed to make an impact in his society with his ideas due to lack of opportunity [5]. However, several hundred years later, the social and political ideas of Confucius which were recorded in The Analects of Confucius proved to be world transforming. In $136 \mathrm{BC}$, the newly founded Chinese State of Han adopted Confucianism as its official ideology following China's short-lived experience with legalism. This made the dream of Confucius of being an adviser to a great ruler to be fulfilled four centuries after his death. He indeed became "a king without a crown" [5]. For the next two thousand years, Chinese scholars sought to interpret and modify Confucianism to make it more relevant in particular situations with original features. By the late nineteenth century, the whole East Asian region was "Confucianized" [1]. Confucian values and practices are thought to have informed the political systems and daily lives of people in China, Korea, Japan, and Vietnam, and even other nations beyond.

\section{Problem Statement and Purpose}

In most normal universities in China, Confucian courses are included in the international students study programs. At East China Normal University (ECNU), the Confucianism studies are embedded in the practical course called Education Practicum and Field Work. The course is intended to help students develop a solid understanding of Chinese education system and its policies from the cultural perspective. During our stay in China, our class of 2017/18 travelled to Qufu in Shadong Province where we visited the temples of Confucius and Mencius and attended to the International Confucius Cultural Festival, as well as the Confucius memorial ceremony. Most of the students in this class were from Africa. Africans have deep rooted cultural history, just like Chinese, which had gradually been discarded and forgotten when the foreign missionaries came to introduce their religions such as Christianity and Islam in the Nineteenth and Twentieth Centuries, and made African traditions look like evil. Meanwhile, Africa continues to face a lot of challenges chiefly caused by moral degradation in most of its countries in which corruption, power struggles and resistances, uncontrollable killings of innocent people and massive degradation of public services are the order of the day. On the other hand, China continues to open itself to the rest of the world, but still able to preserve and uphold some fundamental traditional and cultural aspects such as Confucian ideologies.

Chinese Government provides scholarships to African students in Chinese universities partly to enable them learn from Chinese context to apply and improve situations in their respective countries. However, little is known if the in- 
clusion of Confucian lessons has an impact on these students. Do African students in China take back home valuable lessons from their Confucianism experiences? This article therefore aimed at analyzing Confucius ideas on education and leadership as well as the views of international students on Confucian philosophies, and their reflections on how Africans can benefit from the ideas and philosophies of this Great Sage.

\section{Methodology}

In this qualitative study, I used phenomenological approach in examining the phenomenon of the Great Sage, Confucius and his ideas on education and leadership, utilizing the personal narrative of my reflections as well as the views of 10 individuals; seven of them my former classmates at East China Normal University and the remaining three, former students from other normal universities in Beijing and Shanghai. These ten respondents were from various African countries such as Tanzania, Zanzibar, Democratic Republic of Congo (DRC), Malawi and Nigeria. I basically used face to face interviews as well as WhatsApp messenger to interact with them to collect their reflections regarding their studies of Confucius, his teachings and the lessons they took home to Africa. Phenomenology provided a lens through which respondents were given an opportunity to express their deep rooted feelings, experiences and how they basically committed themselves to the new phenomenon which they were exposed to in the Confucian lessons, and how (if at all) the new knowledge and experience consequently ended up influencing their actions and behaviors [9]. Personal narrative methodology was used to help me in understanding how African students made sense of the valuable principles of Confucius and how they later on, helped them shape their thinking and their interaction with their social world which are different from Chinese world after returning back home [10].

\section{Confucius and His Ideologies}

Many scholars have written a lot on Confucius and Confucianism's teachings as well as philosophies [2] [3] [5] [6] [11] [12] [13]. It is interesting to note that these scholars have recorded Confucius' contributions in many aspects including in education and leadership.

\subsection{Confucius on Education}

Confucius had an early influence on education reforms in China and other countries due to his valuable ideas. Some of his contributions, philosophies and influences are as below:

\subsubsection{Confucius as a Great Scholar and Teacher}

After studying a lot about Confucius, I have resolved that this Great Sage was more of an educator than a leader. He spent most of his time on earth studying, teaching and writing. He wrote very powerful books of wisdom even though he was very modest to take all the credit. For he claimed that what he was writing 
was not his original ideas, "I transmit but I do not create. I am sincerely fond of the ancient. I would compare myself to our old Peng who was fond of talking about the good old days" [5]. Nevertheless, his writings made very strong foundations of education in China. This is because after Confucianism was adopted as a Chinese nation way of life in 136 B.C., it formed the basis of the Chinese education system for 2000 years. His teachings motivated all Chinese people regardless of age and status to study in order to attain power, respect and influence in their society. Confucius once said "study as if you were never to master it, as if in fear of losing it."

\subsubsection{Confucius as the Founder of the First Free School}

Confucius is often accredited with establishing one of the early formal educational institutions in the world. According to [6], Confucius taught his students the classical learning that included the study areas that Confucius himself had gone through as a boy and young man such as poetry, history, literature, ritual, and music. While he taught traditional subjects, he was always interpreting these classical studies in his own way. Confucius interpreted history, poetry, ritual, and music, teaching them as a foundation for moral behavior and good government. Nevertheless, he might be thought as the first person to offer bursary and scholarships to the needy students since he accepted every student willing to learn even those who did not have money to pay. He really wanted education to reach out to everyone in the society.

\subsubsection{Confucius-“Education for All” Concept Originator}

Confucius is also credited to have been the first one to conceive and envision the idea of "education for all". Confucius preached the concept of "Education without distinction" over 2500 years ago [6]. He believed that education and learning should be open and be accessible to everyone. That is why Confucius was open to teaching everyone, no matter who they were in terms of social class or wealth. It is amazing to see that the United Nations decided to adopt and implement "Education for All", the longtime Confucius dream, as an international education theme at Jomtien in Thailand in 1990 which was later reaffirmed at the 2000 World Education Forum in Dakar in Senegal [14]. Further to that, in the Millennium Development Goals, established in 2000, the world governments committed to achieving universal access to free, quality and compulsory primary education by 2015. Currently, it is being heard that the UN has adopted the theme "learning for all". This just shows that Confucius will always live in China and beyond through his great ideas in education.

\subsubsection{Confucius Influenced and Motivated Thirst of Education on Many Chinese}

Throughout the history, Confucius ideas on education have influenced and motivated people in China. In order for one to get a good appointment in government they needed to study very hard to pass the state-run examinations. This even made ancient communities invest in their children vehemently for 
them to succeed since their success could uplift the whole family and even the entire community. For example, if a child was showing potential that he can do well in education, the family would do anything to set him aside for intensive teaching and training. Families could even build special "scholar towers" where the student was locked in day after day, year after year to study for the possibility of his success [5]. Confucius idea that scholars belong to higher social class is still shaping the Chinese society up to date [12]. Chinese people believe that educational success leads to a better life, including higher social status, getting a good job, or a better marriage and relationships, making education to be central to most Chinese families, hence their motivation to acquire more education. The government is also investing in education tremendously to honor the wishes of this Great Sage, Confucius.

\subsubsection{Confucianism, the Originator of Hierarchical Educational System} Confucianism has also influenced the hierarchical educational system which is being practiced all over the world. In old China, one needed to attend and pass a centralized national examination to become successful in education and reach high social status through an official position [11]. The educational system was clearly structured and well-established hence educational achievement was visible and measurable. Up to now, it is believed that earning higher grades, attending higher ranking schools, and receiving higher degrees are indisputable routes to success in China [12]. Nowadays, almost all countries of the world are using the hierarchical educational system which was modeled by Chinese people thousands years ago.

\subsection{Confucius on Leadership}

It is not a secret that Confucius desperately wanted to be a leader in his time. He had leadership ideas that he really wanted to put into practice. He was inspired by the Duke of Zhou from the Book of History who established the Zhou dynasty in China in 1045 B.C. [5]. He considered the Duke as an ideal ruler. It was recorded that the Duke of Zhou was neither selfish nor power hungry who governed his people with justice and mercy. He took care and protected widows, orphans, and even other weak and helpless citizens. Among the activities the duke declared as crimes capable of being committed by leaders was their failure to serve the people well. It was Confucius's greatest dream to find a duke in his own time who would rule just the way the Duke of Zhou did. But he never succeeded. Because of this, he failed to join politics in his time, hence the reason for his failure to acquire a respectable position in government and his society [5]. Therefore, most of the Confucius' ideas of leadership are fashioned on the leadership style of this great duke. Below are some of the greatest concepts and ideas of leadership according to Confucianism:

\subsubsection{Confucius Ideas about Respect of Authority and Order}

Amongst Confucius' important teaching on leadership, he taught that subjects 
should respect the ruler at all cost in order to achieve order and harmony. According to him, the society would be harmonious when each person understands his or her proper role and acts accordingly; "let the ruler be a ruler and the subject a subject" he said [5]. Central to Confucianism is the idea that people should live in harmony, both with each other and with nature. Obviously, if people do this in a society, that society would live in peace and harmony.

\subsubsection{Confucius on Leaders' Life of Exemplary and Virtue}

Confucius did not just stop on subjects; he also had a very important advice to leaders. He preached that government leaders were supposed to be exemplary and men of virtues. To Confucius, government service was the highest calling in someone's lifetime. Therefore, a government official needed to live like a gentleman. According to him, "a gentleman first practices what he preaches and then preaches what he practices" [6]. That is why he emphasized that every government official has to be properly trained and educated before entering government noble services. Education was, according to Confucius, the ultimate tool of reaching the high standard of a virtuous gentleman.

Confucius taught five virtues to his disciples so that they could acquire the status of gentlemen. These were virtues of courtesy, magnanimity, good faith, diligence, and kindness. Other scholars added the virtues of dutifulness or loyalty, honesty, knowledge, rightness, courage and understanding [6]. In the virtue of dutifulness or loyalty, Confucius taught people to put the interests of their superior, whether fathers or rulers, before their own [6]. Private ambitions must be subordinated to one's highest loyalty. On the virtue of honesty Confucius taught that a leader is not supposed to make sweeping promises; he should only speak when he is capable of delivering what he saying he can do and be sincere, not just lying hence calculating his own advantages. He said a leader should be capable of "setting words right" [6]. In the Confucianism philosophy, for a leader to be sincere, he needs to know what is right. Confucius revealed that knowledge or wisdom is something that a person may not be born with, but, for him, it is always something that anybody can work to achieve [6]. To Confucius, a man with these qualities was qualified enough to be given a responsibility of governing the state.

\section{African Students' Reflections and Lessons Learned from Studies of Confucianism}

The study used qualitative data from ten respondents as well as from my own self interview. From the analysis of the data, it was clear that almost all of the respondents did not have prior knowledge of Confucianism before they set their feet in China, except three people who indicated to have had scanty knowledge of this man and his teachings from the books they read as well as from Confucius Centers in their countries. However, just as my experience, all respondents involved in this study admitted that their Confucianism studies made them change the way they viewed life after learning a lot in class and from various fa- 
cility visits they had at various Chinese cultural and historical establishments whilst in China. The following were among the most important things I and the majority of the respondents reported to have learned:

\subsection{Confucius Will Forever Have Global Influence through His Classical Quotations}

Since the majority of the respondents reported that they did not have prior knowledge of Confucius and his teachings before landing in China, it was fascinating to still note that most of them were impacted by the teachings of Confucius unknowingly. This was because almost all of them admitted that they came across or learned some popular wise sayings of Confucius long time ago not knowing that the author was an ancient Chinese Sage. Some of the respondents even realized that they had been frequently using those quotations in their professional growth and daily lives. Some of these quotations and wise saying related to education which this group of African students mentioned were as follows;

"Education breeds confidence. Confidence breeds hope. Hope breeds peace."

"By three methods we may learn wisdom: First, by reflection, which is the noblest, second, by imitation, which is easiest, and third by experience, which is the bitterest."

"Learn as though you would never be able to master it, hold it as though you would be in fear of losing it."

"Knowledge is recognizing what you know and what you don' t."

"He who knows all the answers has not been asked all the questions."

"You cannot open a book without learning something."

Apart from educational quotes, these ten respondents also revealed that they came across other common wise sayings that they realized later in their lessons in China that they were Chinese quotations by Confucius, some are listed below:

"Life is really simple, but we insist on making it complicated."

"In a country well-governed, poverty is something to be ashamed of. In a country badly governed, wealth is something to be ashamed of."

"It does not matter how slowly you go as long as you do not stop."

Personally, from the past, I have been inspired by the quotation "I listen and I forget ... I do and I understand". Honestly, I did not know that it was one of the most valuable Chinese sayings of Confucius until now. These quotations and many otherwise sayings are used every day around the world for education purposes. They are even used by people who do not even know about Confucius, as evidenced in this study; undoubtedly the multitudes have been positively impacted by the wisdom from Confucius' recorded sayings circulating around the world. This just shows the influence that Confucius continues to make all over the world thousands years after his death with his ideas. If adopted and used sincere by world leaders and peoples, I believe Confucianism would surely contribute to changing the world and making it a better place to live for everyone. 


\subsection{Africans Need to Reawaken Their Long Forgotten Cultural Values}

On the question if Confucian principles were similar to African traditional philosophies, all respondents indicated that most of Confucian philosophies were similar to those traditional principles that were passed from generations to generations in typical African settings. According to them, Africans were traditionally known with embracing the traditional culture of community values such as respect of the elders in the society, patriotism, selflessness, veneration of the ancestors and the strong value on community sharing of resources. All these values are also at the heart of Confucian philosophy. In concurring to this finding, some scholars observe that Confucian and African philosophical traditions are both characterized as "relational" in contrast to the "individualism" which is common in most Western philosophies [2] [3] [13] [15]. According to [2], Confucius centralized his teachings on zhong, $l i, y i$ and ren which mean loyalty, ceremony, righteousness and humanness respectively, which are common in many African traditions beliefs which [15] related to the African traditional concept of Ubuntu. It is also argued that in both African tradition and Ancient China, an individual is most appropriately conceived as a moral person whose life and existence is significantly reliant on others [3]. This is why in many African societies, the elders of the tribe or family have a very important say on very important life decisions of an individual such as marriage, upbringing of children as well as funerals.

However, these respondents were quick to note that, as opposed to majority of Chinese people, who seemed to continue embracing some of their traditional values up to now, most Africans have discarded most of these values chiefly due to their embracing of the Western individualistic philosophies which generally promote individuals' satisfaction as opposed to the whole society, as observed by a number of researchers as well [16] [17] [18]. These were partly brought by the early missionaries who preached that African cultures and traditions were evil hence encouraged their subjects to completely abandon some of their cultural aspects and values. The respondents noted that individualization has brought in a lot of problems such as corruption, theft of government resources and the civil wars. Most political leaders are no longer serving in government for the benefit of their people but to enrich themselves, the people are also no longer patriotic to their governments and societies. China has achieved extreme multidimensional development and progress perhaps partly because Chinese continue to embrace some of the very important traditional ideologies which include Confucian principles.

It is a known fact that Confucius encouraged people to know and honour their roots so as to keep their identity [2]. If he was alive now, I believe Confucius would have the same advice to Africans that they need to go back to their cultural roots and embrace the incorrigible lifestyle of their ancestors with virtues such as patriotism, community ownership, and selflessness. This would help 
in alleviating many of the social and economic problems that most of African countries are facing right now. Confucius society faced many of the same problems such as corruption, but the applications of Confucius ideas later after his death bailed them out of poverty. Similarly, our society seems to be losing respect for morality and ethics. Confucius offered solutions to these problems. He said that we can become responsible leaders who behave exemplary to produce positive impact and change on our followers [6]. If we can do that, we can change the world we live in, just as the way the Chinese have managed to change their world.

\subsection{Confucius's Golden Rule on Leadership}

All respondents engaged in this study acknowledged the value of the golden rule taught by Confucius which is also found in Christianity. Confucius taught a moral code based on ethics, humanity, and love. The most interesting thing was his golden rule, which can be found in every book of wisdom of earth including the Bible. In response to a question by one of his disciples who wanted Confucius to describe in one word the whole duty of man. Confucius replied that: “... Do not do to others what you would not wish them to do to you." [5]. Jesus, in Matthew 7 verse 12 also preached similar golden rule of Christianity hundreds of years later. Jesus said "... in everything, do to others what you would have them do to you, for this sums up the Law and the Prophets". Perhaps one of the prophets which Jesus was referring to was Kŏng Fūž̀ [孔夫孔] whom we are referring to as Confucius. This makes sense, honestly who wants others to hurt him or her? Nobody. If all African leaders embraced fully this principle, I do not think cases of corruption and looting of government resources would have been the order of the day. I also do not think that we should have been talking about wars and the killing of innocent people in many African countries. This discourses would have been nonexistent because nobody wants to be killed by someone, hence nobody ought to do evil to another. This just shows that this man was indeed one of the greatest sages ever lived on earth. Thus, from very early times, this "golden rule" became an important part of Chinese thought.

\subsection{Virtuous Life Is the Only Source of True Happiness}

As opposed to accumulation of wealth in search for happiness, the respondents in this study acknowledged to have learned a very important tip to true happiness. According to them, they learned that true happiness cannot only be found in wealth or high statuses, but in living a virtuous life. Confucius was not caught up in worrying about wealth and status; he only wanted to be in government to bring about change. But when he failed to convince the authorities in his time, he did not go to war to forcefully fight for the people and probably overthrow the oppressive leaderships, nor compromised on his virtues to gain favors of the rulers to acquire government position. He instead decided to dedicate his time teaching the young minds to apply his ideas in the future. Instead, he was very 
happy with simple things such as swimming and singing with his friends. He once said "Eating plain food, drinking water ... there is joy in this! Wealth and high position-when gotten improperly-as far as I am concerned are nothing more than passing clouds" [6]. Imagine, everyone in Africa embraces this line of thinking, can corruption and theft of government resources continue? Do you think cases of civil demonstrations or unrests, strikes for pay rise and others would be prevalent in African countries? No wonder the Chinese are tremendously progressing and developing because they have been properly enlightened by this Great Sage's teachings.

\subsection{The Need to Serve the People Selflessly}

The respondents also indicated that they were inspired by Confucius principle that the priority of every leader should be serving the people. One of the respondents had this to say:

"The major problem of Africans is selfishness. Selfishness is leading to so many problems we are facing in our countries. I think if we can imitate the selflessness act of Confucius, then it will go a long way"

This is what Confucius preached. He maintained that government exists for the benefit of the people. The first and necessary step in good governance is to put words straight, so that everyone knows what is going on and how to behave. Caring for the common people meant ensuring that basic needs, like food, clothing and shelter, are met. It is crucial that the economy allow people to make a decent living. Even taxes should not be punishing to limit people's progress. I can now relate to how the current Chinese Government is taking care of its people. A good example is the cheapest and good transport system affordable to everyone in the country. Further to that, Chinese Government has invested and is still investing a lot in education sector at all levels, from elementary, high school to higher education. The infrastructures available in universities in China are just a dream to many African countries. Nevertheless, this is doable and achievable in African countries as well, only if our leaders start using national resources for the benefit of their people, such as creating more jobs by opening more public companies not selling them, and also strengthening infrastructural development by coming up with meaningful construction projects, not just waiting for the private sector or international donors such as from United States of America, China and European Union to do that. With very rich mineral and agricultural resource base of many of the African countries, this is achievable.

\subsection{Leaders Need to Be Role-Models of the People}

All of the respondents in this qualitative study also reported to also have learned a lot on being role-models when one is privileged with a government position. According to them, in Africa, crimes such as corruption, theft and robbery are at an alarming rate. According to one of the respondents from Nigeria, if all government officials would learn Confucianism philosophy, the situation would 
automatically change for better. The respondent noted that it was the leaders who were the first plunderers of public resources; hence their followers do the same.

During Confucius time, a government official in the State of $\mathrm{Lu}$ complained to Confucius about the rising number of robbers. Confucius told him that if he got rid of his own desires for luxury, ordinary people would not steal, even if they were paid to do it [6]. This makes sense. Confucius was convinced that government officials were supposed to act as role-models for the people in order to make people live in peace and harmony [6]. If people see their leaders as sincere, honest and hardworking, they would also become sincere, honest, and hardworking as well. Confucius said, "the virtue of the gentleman is like the wind and the virtue of the common people is like the grass: when the wind moves, the grass is sure to bend". Using this principle people would move in the direction that their leader leads them. Therefore, if the government ministers and officials are corrupt, so will the people be; if government officials are patriotic, people will also be patriotic. Therefore, leaders really need to live a virtuous life, so as to model their followers hence achieve development in the long run.

\section{Conclusion and Implications}

From the results of this study, the majority of respondents acknowledged that they indeed took home a lot of lessons from their studies on Confucius and his philosophies. It was found that Confucianism studies can make students change the way they viewed life. The study found out that they are many people in the world who use Confucius wise sayings and quotations in their lives not knowing that the author was a Chinese Sage. It has also been observed that Confucian philosophies were similar to those traditional principles that were passed from generations to generations in typical African settings; however, most Africans have discarded most of these values as opposed to most Chinese who seem to still embrace some of the most valuable traditional principles. This has contributed to the moral degradation in most African societies. It was also found out that Confucius studies made foreign students who are serious in them to understand the values of the leaders being the role models and the need for them to selflessly serve the people, and the importance of living a life of virtues.

Due to the involvement of a very small number of respondents (ten), the findings of this study cannot be generalized on all African alumni of all Chinese Universities. Nevertheless, from the findings of this study, it is now clear to me as to why Confucian philosophy has been and will be extremely valuable in the fields of education, philosophy and leadership worldwide. Even though Confucianism might have undergone an evolution as the centuries were passing, certain core ideals have evidently remained. It is indeed clear that Confucius's teachings and philosophy formed a foundation and is still contributing to a number of modern education ideologies such as education for all, universal education and education for public good. We can comfortably speculate that the 
Chinese Government borrowed some of its great ideologies used in most educational and leadership policies from this philosopher hence massive development in China. Africans need to learn something from these ideologies.

\section{Conflicts of Interest}

The author declares no conflicts of interest regarding the publication of this paper.

\section{References}

[1] Bell, D.A. and Chaibong, H. (2003) The Contemporary Relevance of Confucianism. In: Bell, D.A. and Chaibong, H., Eds., Confucianism for the Modern World, Cambridge University Press, Cambridge, 1-28. https://doi.org/10.1017/CBO9780511509964

[2] Jama, S. (2017) Similarities between Chinese and African Culture. The Patriot. https://www.thepatriot.co.zw/old posts/similarities-between-chinese-and-african-c ulture

[3] Igbafen, M.L. (2014) The Concept of Person in African and Chinese Philosophies: A Comparative Inquiry. International Journal of Philosophy and Theology, 2, 121-149. https://doi.org/10.15640/ijpt.v2n3a10 http://ijptnet.com/journals/ijpt/Vol 2 No 3 September 2014/10.pdf

[4] Zhiling, L. (2013) Confucius: The Man, His Ideas and Ideals about Learning and Education. http://www.philadelphia.edu.jo/centers/confucius/pdf

[5] Hoobler, D. and Hoobler, T. (2009) Confucianism. 3rd Edition, Chelsea House, New York.

[6] Rainey, L.D. (2010) Confucius and Confucianism: The Essentials. Wiley-Blackwell, Oxford. https://doi.org/10.1002/9781444323603

[7] Berthrong, J.H. and Berthrong, E.N. (2004) Confucianism: A Short Introduction. One World Publications, Oxford. https://doi.org/10.1111/j.0301-8121.2004.155 2.x

[8] Taylor, R.L. (2004) Confucianism. Chelsea House Publishers, Philadelphia.

[9] Peterson, E.E. and Langellier, K.M. (1997) The Politics of Personal Narrative Methodology. Text and Performance Quarterly, 17, 135-152. https://doi.org/10.1080/10462939709366178

[10] Van Manen, M. (1990) Researching Lived Experience: Human Science for an Action Sensitive Pedagogy. State University of New York Press, Albany.

[11] Lien, L.Y. (2006) Creating a Successful Educational Path for Children: The Experience of Taiwanese Mothers. Annual Conference of the National Council on Family Relations, Minneapolis, November 2006.

[12] Huang, G.H. and Gove, M. (2012) Confucianism and Chinese Families: Values and Practices in Education. International Journal of Humanities and Social Science, 2, 10-14. http://www.ijhssnet.com/journals

[13] Metz, T. (2017) Confucianism and African Philosophy. In: Afolayan, A. and Falola, T., Eds., The Palgrave Handbook of African Philosophy, Palgrave Macmillan, New York, 207-221. https://doi.org/10.1057/978-1-137-59291-0 14

[14] UNESCO (2007) A Human Rights-Based Approach to Education for All. A Framework for the Realization of Children's Right to Education and Rights within Education. United Nations Children's Fund, New York.

[15] Bell, D.A. and Metz, T. (2011) Confucianism and Ubuntu. Journal of Chinese Phi- 
losophy, 38, 78-95. https://doi.org/10.1111/j.1540-6253.2012.01690.x

[16] Dare, A. (2010) The Effects of Western Civilization and Culture on Africa. Afro Asian Journal of Social Sciences, 1, 1-13.

[17] Chulu, J. (2015) Africa Is Largely Influenced by Foreign Culture Especially Western Culture. Has Africa Now Sacrificed Her Own Culture on the Altar of Expediency? https://doi.org/10.2139/ssrn.2671784 https://papers.ssrn.com/sol3/papers.cfm?abstract id $=2671784$

[18] Wahab, E.O., Odunsi, S.O. and Ajiboye, O.E. (2012) Causes and Consequences of Rapid Erosion of Cultural Values in a Traditional African Society. Journal of Anthropology, 2012, Article ID: 327061. https://doi.org/10.1155/2012/327061 